\title{
Study on the Influential Factors of Village Cadres' Work Enthusiasm in Supply of Village-level Public Goods: Based on Survey Data in Fujian Province
}

\author{
Xiuyi $\mathrm{Li}^{1,2, a}$, Weiping Liu, ${ }^{1, b^{*}}$ and Xiaoyan Xing ${ }^{3, \mathrm{c}}$ \\ ${ }^{1}$ School of Economics, Fujian Agriculture and Forestry University, Fuzhou, Fujian, China \\ ${ }^{2}$ School of Public Affairs, Fujian Jiangxia University, Fuzhou, Fujian, China \\ ${ }^{3}$ Departments of Management, Fujian Chuanzheng Communications College, Fuzhou, Fujian, China \\ a75585480@qq.com, blwp789326@126.com, '893592249@qq.com \\ ${ }^{*}$ Corresponding author
}

Keywords: "One Case, One Meeting" mechanism; Village cadre; Village-level public goods; Village cadres' work enthusiasm

\begin{abstract}
One Case, One Meeting" has become the basic mechanism in the supply of village-level public goods. After the mechanism innovation in 2008, many villages were witnessed to break through the collaborative dilemma in "One Case, One Meeting". The existing research put more emphasis on financial reward in villagers' collaboration, ignorant of the critical role of village cadres, not to mention which factors transform village cadres' behavior from "idleness" to "entrepreneur" in the supply of village-level public goods. Based on cases in Fujian Province, by means of quantitative analysis ,the author obtained a results that national performance assessment, election and villagers' meeting have significant impact on village cadres' work enthusiasm in "One Case, One Meeting" mechanism. The author concluded that if we want to motivate village cadres spent more effort in the supply of village-level public goods, we should improve the mechanism of village cadres' incentive and evaluation, fully employ role of villagers' meeting.
\end{abstract}

\section{Introduction}

Background. China's rural public goods supply mechanism has undergone tremendous changes since 2000: the supply of basic public goods and services in rural areas was up to government finance; whereas the supply of quasi-public goods such as small village irrigation, road and bridges, sanitation facilities, public facilities used inclusively by villagers was up to "one case, one meeting" system, which means it is the villagers who discuss, decide, finance, and construct the quasi-public goods.

However, statistics from the Ministry of Finance, showed that the supply of village-level public goods has stagnated from 2000 to 2008,the number of villages built public projects through the "One Case, One Meeting" mechanism accumulated to 2008 was less than 14\%[1].So the government innovated the mechanism by providing financial awards to match investment from villagers, accounting for 50\% of villagers' investment, meanwhile [2],"One Case, One Meeting" was used to appraise local government' performance. Good results were achieved by this innovation: data from the Ministry of Finance showed by 2012, the number increased from 14\% in 2008 to 37.3\% [1].Data from Department of Finance of Fujian province, which started to complement village's public construction, showed that the number of villages received financial awards was 7443 , accounting for $51.56 \%$ only in the year 2011.Therefore,the author named this financial awards period as the new "one case, one meeting".

Issues raised. Most scholars attributed the reduction of villagers cooperation cost and improvement of villagers' participatory enthusiasm to the successful implementation of financial awards, neglected or not gave due attention to roles played by village cadres. In fact, village cadres pay a huge effort to 
integration of the villagers' will, funds collection, project construction and maintenance[3,4].Some scholars noticed village cadres' key role in the development of "one case, one meeting" project, but gave no further discourse[5,6].This essay will take village construction of public goods in Fujian Province as an example, in order to identify factors contributing to villager cadres' working enthusiasm, and what can do to improve their enthusiasm.

\section{Text Theoretical Analysis of Influential Factors of Village Cadres' Behavior}

Since the village main cadres, including village chief and village party secretary, are responsible for trunk village affairs, the village cadre used in the essay refers to the village main cadres. In the background of villagers 'autonomy, village cadres (especially the villagers' committee) are elected by villagers, but "employed" and assessed by town government, so their behavior is also subject to the dual constraints from demands of both villagers and government. Oi Jean and others noted as "dual representative of the interests of the government and villagers," village cadres strike a balance between the will of the government, the requirements of villagers and their interests [7].This paper holds that financial awards encouraged villagers to participate actively in "one case, one meeting" program, also asked the village cadres to actively contribute to public welfare projects, government motivated village cadres by adjusting the village cadres performance evaluation indicators, putting more importance to village public construction. That is to say, the dual pressures from both villagers and government have substantial influence on village cadres' behavior. L. J. Li and others noted that their behavior was impacted by wages and job generation method [8]; L. X. Zhang noted that gender of village cadres, and village scale also affect their behavior [9].

\section{Empirical Analysis}

Data Sources. From January 2013 to March 2013, the study had conducted a questionnaire survey on village cadres from 203 villages in the prefecture-level city in Fujian. Survey data show that only $9.6 \%$ of the villages had carried out village-level public construction before 2008, and from 2009 to March 2013 we witnessed the ratio was $70.86 \%$, with 256 public projects constructed in total. Village cadres played a key role in the process, with $58.58 \%$ and $89.45 \%$ being initiated and implemented by the village committee respectively.

Variables Description. Village cadres are not full-time civil servants, they can flexibly allocate time spent on public issues or private issues, this or that issue. The more time spent on "one case, one meeting" issues, the more beneficial to the construction of village-level public welfare facilities[10].Therefore, the estimated ratio of time spent on "one case, one meeting" issues versus total working time was chosen to be the dependent variable. Based on data of the ratio in 2012, the author assumed that:the higher the ratio, the better. Explanatory variables are as follows:

(1)Influences from government. One is the importance of construction of village-level public project in the performance appraisal system, the other is wages paid to village cadres. We assumed that: more emphasis on construction of village-level public and higher wages prompt village cadres to put more time in public issues.

(2)Influences from villagers. Firstly, because of village cadres' are elected by villagers, they respond positively to villagers' requirements. Secondly, the villagers meeting times. We assumed that: more meeting times prompt village cadres to put more time in public issues.

(3)The village characteristic variables. Including the village numbers, distance from village to town.

(4) The village cadre's personal characteristics. Village cadres age, education level, gender and the number of family members need to be supported will also affect the ratio. We assign "1" for male, "0" for female. Female cadres may want to spend more time on family compared to male, so gender may 
have influence on time spent on public issues. We assumed that: the more members need to be supported, the less time spared to public issues.

(5) How much village migrant workers are paid also has impact on the ratio. Being village cadres means giving up the wage obtained as migrant workers. So we assumed that: the more village migrant workers earn, the less the ratio.

Empirical Results and Analysis. Based on main variables' statistical features, using STAT12 statistical software to process data, taking OLS estimation method, a one-time regression. the regression results in Table 1 show that the model simulation is better, goodness of fit is 0.3372 ; and at $1 \%$ significance level. Specific analysis of the results is as follows.

Table 1 Regression results of influential factors of village cadres'

Working time ratio in the "One Case One Meeting"

\begin{tabular}{|c|c|c|c|c|}
\hline variable & $\begin{array}{l}\text { coeffic } \\
\text { ient }\end{array}$ & $\begin{array}{r}\text { standard } \\
\text { deviation }\end{array}$ & $\mathrm{Z}$ & $\mathrm{F}$ \\
\hline $\begin{array}{c}\text { Importance of village } \\
\text { public welfare project in } \\
\text { village cadres' performance } \\
\text { appraisal }(1=\text { high, } 0= \\
\text { low })\end{array}$ & 8.676 & 1.879 & 4.62 & $0.000 * * *$ \\
\hline age & -0.062 & 0.118 & 0.52 & 0.602 \\
\hline Sex $(0=$ male, $1=$ female $)$ & -1.912 & 2.900 & -0.66 & 0.510 \\
\hline $\begin{array}{l}\text { Meeting times of villagers' } \\
\text { representatives }\end{array}$ & 3.152 & 0.523 & 6.03 & $0.000 * * *$ \\
\hline Salary of village cadre & 2.782 & 3.203 & 0.87 & 0.386 \\
\hline $\begin{array}{c}\text { The number of family } \\
\text { support }\end{array}$ & -0.133 & 0.600 & 0.22 & 0.825 \\
\hline Number of villages & 0.078 & 0.039 & 1.98 & $0.058 *$ \\
\hline Education & 0.058 & 0.340 & -0.17 & 0.864 \\
\hline $\begin{array}{l}\text { Distance from village to } \\
\text { town }\end{array}$ & 0.055 & 0.132 & 0.42 & 0.675 \\
\hline $\begin{array}{l}\text { Cadre posts }(0=\text { secretary, } \\
=1=\text { the village director })\end{array}$ & 3.465 & 1.451 & 2.39 & $0.018 * *$ \\
\hline $\begin{array}{l}\text { Village migrant workers } \\
\text { wages }\end{array}$ & -0.002 & 0.001 & -2.59 & $0.051 *$ \\
\hline Intercept & 6.431 & 7.943 & 0.81 & 0.419 \\
\hline
\end{tabular}

Note: $* * *, * * *$ represent statistically significant at the $10 \%, 5 \%$ and $1 \%$ level respectively.

Critical factors influencing village cadres' working enthusiasm are as follows:

(1) Influence from government .First, government putting more importance to village-level welfare in the performance appraisal system, can significantly affect village cadres' working time ratio in the 
"One Case,One Meeting",significant at the $1 \%$ statistical level; second, influence of salary on village cadres' working time ratio is positive, but not significant, which means the role of salary in motivating village cadres is not as important as imagined. Many village cadres surveyed claimed that they pay more attention to the right to collective resource allocation, contact brought to their business, and the corresponding fame status, social security.

(2) Influence from villagers. First, the meeting number of villagers has a positive impact on time spent on "one case, one meeting" by village cadres and significant at the $1 \%$ statistical level.

Second, the election procedure contributes to enthusiasm for work, and positively affects the village cadres' enthusiasm more than the secretary, significant at the 5\% statistical level.

(3) Influence from other factors. First, the village migrant workers' wages have a negative influence on village cadres' working time, but significant only at the $10 \%$ statistical level. Maybe village cadres are deprived of other working opportunities, the more village migrant workers' wages earn, the more opportunity cost to village cadres, the less time they put in "one case, one meeting". Second, the number of villages has positive effect on village cadres' working time, and significant at the $10 \%$ statistical level.

\section{Conclusions and Policy Recommendations}

Empirical results show village cadres, are "double agent of government and villagers ",whose time spent on "one case, one meeting" issues is significantly affected by requirement of government and villagers. The impact of wages is not significant, perhaps non-wage returns brought by the position is more valued than a specific salary.

Based on these conclusions, in order to motivate village cadres spent more time on "one case, one meeting" issues, the following items should be noticed:

Firstly, improve village cadres' performance evaluation mechanism to make "village public welfare projects" account for prominent share; determine village cadres in reference to migrant workers' wages, make sure it is equal to or moderately above migrant workers' wages, basic wage should be correlated to village scale; while combine wage and non-wage motivations, we should notice that hidden motivation, intrinsic motivation, and prestige incentives also play due role in motivating village cadres.

Secondly, fully employ role of villagers' meeting, make sure meeting be held regularly, to supervise village cadres' behavior; plus, perfect the direct election mechanism, make the election of village cadres reflects villagers' demands.

Last, strengthen cooperation between government and villagers, common requirements of the two party can promote the "double agent" to devote more energy to "one case, one meeting" issues.

\section{Acknowledgements}

This paper is one of the periodic accomplishments of the National Social Science Fund Project, namely, "government - Village relations and crack of dilemma of collective action in the supply of village -level public goods (15BGL178).

\section{References}

[1] Hu Jinglin; Innovate the "One Case, One Meeting" Mechanism, Rural Finance, 2013 NO.7, p.2-4.(In Chinese).

[2] Li Xiuyi, Liu Weiping; The Solution to the Cooperation Dilemma in rural after the Complementation of Financial Reward_-a Case Study about 39 Villages in Fujian, Journal of Agro-Forestry Economics and Management, vol. 14 (2015), p.91-100.(In Chinese) 
[3] Zhou Mi, Zhang Guangsheng: The Operation Mechanism of "One Case, One Meeting" System and its Applicability, Issues in Agricultural Economy, 2010 ,No.2, p.38-43.(In Chinese)

[4] Tu Shengwei: Community,Enterprise,Cooperative Organization and Rural Public Goods Supply,Economic Science Press,China,2011:22-24.(In Chinese)

[5] Yu Liyan:Analysis on the Main Factors of "One Case, One Meeting" System of Rural public goods Supply:Based on Survey Data in Fujian Province, Issue in Agriculture Economics, vol. 29 (2015), NO.3, p.34. (In Chinese)

[6] Chenjie, Liu Weiping, Yu Liyan: Study on Performance and evaluation of "One Case, One Meeting"financial subsidy system_— take Fujian Province as an example,Fujian Tribune (The Humanities \& Social Sciences Bimonthly), 2013,No.9, p.135-138.(In Chinese)

[7] JC. Oi , S. Rozelle:Elections and Power: The Locus of Decision-making in Chinese Villages, The China Quarterly, 2000,No. 162, p.513-523.

[8] L.J. Li:Elections and Popular Resistance in Rural China, China Information, vol. 15 (2001) No.2, p.2-15.

[9] Zhang Linxiu, Luo Renfu, Liu Chengfang, Scott Rozelle. An Analysis on the Determinants of Public Good Investment in China's Rural Communities, Economic Research Journal, 2005,No. 11, p.76-83. (In Chinese)

[10] R.F.Luo, L.X.Zhang and J.K.Huang and S. Rozelle: Elections, Fiscal Reform and Public Goods Provision in Rural China. Journal of Comparative Economics, vol. 35 (2007), No.9, p.56-57. 